\title{
Uncertain Supply Chain Management
}

homepage: www.GrowingScience.com/uscm

\section{Factors affecting logistics performance in e-commerce: Evidence from Vietnam}

\author{
Nguyen Tien Minh ${ }^{\mathbf{a}^{*}}$
}

${ }^{a}$ VNU University of Economics \& Business, Hanoi, Vietnam

\begin{tabular}{l}
\hline C H R O N I C L E \\
\hline Article history: \\
Received April 7, 2021 \\
Received in revised format May \\
28,2021 \\
Accepted July 72021 \\
Available online \\
July 72021 \\
\hline Keywords: \\
Logistics performance \\
E-commerce \\
E-logistics
\end{tabular}

\section{A B S T R A C T}

The objective of the study is to determine the factors affecting logistics performance in ecommerce in Vietnam. Vietnam's logistics industry with an estimated total value of USD 50-60 billion is currently growing rapidly $(20-25 \% /$ year) and is forecast to maintain double-digit growth for at least the next 5-10 years, due to the breakthrough of the retail industry with the high penetration of the internet and the trend of online shopping. Research has shown 6 factors that have an impact on logistics performance: customer perception, technology and security, customer protection, electronic payment system, human resources, organization and administration. Analysis of factors affecting logistics performance to propose solutions to improve supply chain quality in e-commerce.

\section{Introduction}

Today, with the appearance of smartphones and modern devices in the 4.0 technology industry, people's lives and habits gradually change. Along with the continuous development of the Internet, mobile devices, etc. commerce are also moving in a new direction, applying scientific achievements of 4.0 technology. Traditional commerce is gradually being replaced by Ecommerce and this is a trend that is predicted to grow strongly in the future.

With the continuous development of e-commerce and the increasing demand of consumers, the development of Logistics in Vietnam has not kept pace to meet that demand. According to the Logistics report 2019 of the Ministry of Industry and Trade, the growth rate of e-commerce is $24 \%$ while the growth rate of logistics is only $12 \%-14 \%$, much lower than the growth rate of commerce electronics. That said, urgent measures are needed to improve logistics performance to promote the development of e-commerce - an industry that is trending in the world. Logistics service development is understood as development in breadth or development in depth. Expanding in breadth means increasing the size and sales of Logistics.

Vietnam's e-commerce industry in recent times has made many significant developments. In 2019, the number of people participating in e-commerce was 35.4 million people and generated revenue of more than 8 billion USD, in the list of 10 countries with the fastest growth of the e-commerce industry in the world. Along with the rapid development of the ecommerce market, businesses have also begun to pay attention to the development of logistics in e-commerce because this is an important factor determining the success or failure of enterprises in this field. To strongly develop e-commerce, it is indispensable for quality logistics services. The development of logistics services will help the circulation and distribution of goods be smooth, accurate and safe and is the basis for improving the competitiveness of e-commerce enterprises. Although the logistics sector has developed quite rapidly, according to the authors, academic studies on e-logistics in Vietnam are still very limited. Most of the studies focus on the activities and impacts of the logistics service industry in general at the national or provincial level. However, almost all of the above topics have not specifically mentioned the relationship between e-

* Corresponding author

E-mail address: tiennguyenm306@gmail.com (N. T. Minh)

(C) 2021 Growing Science Ltd. All rights reserved.

doi: $10.5267 /$ j.uscm.2021.7.005 
commerce and logistics activities, especially the development of e-commerce, which will pose any problems for the development of e-commerce activities. logistics action. According to the statistics of the Vietnam E-commerce Association (2020), currently, although the awareness of the benefits of transactions through the e-commerce floor of the government and Vietnamese enterprises has improved significantly, the situation is still not clear. The application of software related to purchasing of Vietnamese enterprises is still quite limited. The government and businesses still mainly apply the traditional form of purchasing. In other words, forms of e-commerce such as B2B or B2G are quite new and account for a small market share in the total size of the e-commerce market in Vietnam. In addition, according to the announcement of the Vietnam Department of E-commerce and Digital Economy (2020), the percentage of Vietnamese users buying goods through foreign websites accounts for less than $30 \%$ of the total number of e-commerce transactions. This means that, at present, Vietnam's cross-border e-commerce activities are considered to have developed, but the size of Vietnam's e-commerce market is still determined by domestic e-commerce transactions.

\section{Literature review}

\subsection{Customer perception}

Perception is the process of selecting, organizing, and interpreting input, the sensations received through sight, sensation, hearing, smell, and touch, to create meaning (Yakup, 2011). Perception depends not only on physical stimuli but also on stimuli related to the surroundings and the condition of the individual involved. Perception of something is very dependent on stimuli and individuals. Triggers are physical characteristics such as size, weight, color, or shape, while personal factors are included in the process not only across the five senses but also in the process of experiencing the future. self and main motivation and expectations of the individual. Benefit, ease of use, self-efficacy, security, trust and perceived usefulness are the main factors that shape customer perception in online shopping (Brosch, 2010; Solvi, 2010; Fiske, 2018).

\subsection{Technology and security}

Online security, also known as web security in general, includes processes for validating business transactions, controlling access to resources such as websites for registered or selected users, encrypting communications and ensuring privacy and transaction efficiency (Panarello, 2018). Among the various concerns in using web services, web security has been a perennial concern among online shoppers. From the incidents that have happened, we can conclude that the lack of security and the fear of hackers are becoming the major influencing factors on their attitudes and intentions to purchase electronic goods. In view of these important factors, e-stores or e-retailers must uphold the importance of security on their website and ensure consumers' data is stored and protected. Appropriately (Wong, 2019; Chakraborty, 2016; Sharma, 2010).

\subsection{Customer protection}

The development of e-commerce has contributed significantly to mediating the display and disclosure of personal information through the internet. Through this unrestricted disclosure, it introduces the concept and debate of privacy in online shopping. Disclosure leaves people vulnerable to exploitation by others because information changes from privately owned to co-owned (Petronio, 2002). It claims that privacy is a serious issue in e-commerce from any research permitting. Many consumers then also began to become aware of privacy issues when making purchases over the internet (Yuniar, 2019). Consumer concerns about privacy in e-commerce transactions as they potentially lose control of their personal information (Metzger, 2007). When making a purchase decision, consumers must provide personal information such as home address, phone number or credit card number. Concerned consumers find it difficult to control what information is presented or submitted later (Glover and Benbasat, 2011). The fact that e-commerce parties do not have security guarantees will cause consumers' personal information to be distorted.

\subsection{Electronic payment system}

An electronic payment system is a method of payment via an electronic network such as the internet (Yu, 2002; Okifo, 2015). In other words, we can say that electronic payment is a method by which a person can make Online Payment for his or her purchase of goods and services without transferring cash and checks, any tell time and place. Electronic payment system is the basis of online payment and development of online payment system is a higher form of electronic payment (Jing, 2009; Singh, 2013). It makes electronic payment at any time through live internet to manage the e-business environment.

\subsection{Human resources}

HRM, according to some authors, serves as a support and a mechanism for managing online obligations and interactions. Menon (2012) discovered that certain HRM practices, such as flexible job descriptions, team organization, collaboration training, and the use of performance indicators, are strongly linked to online shopping success.

The four dimensions are often used variables to represent HRM such as (1) compensation \& benefits, (2) training \& staff development, (3) communication management style; and (4) recruitment and selection of employees (Smith-Doerflein et al, 2011; Hohenstein et al, 2014). 


\subsection{Organization and administration}

Organizations with effective procurement applications create less expensive and more streamlined doors opening for customers in the buying phase. In this way, they make their profits incremental, and their customers better fulfilled (Cakir, 2013). Shopping apps have accelerated thanks to the spread of the web and that has also led organizations to adopt it. In this regard, organizations have created frameworks through which they can speak specifically to their customers and enable them to act without anyone else's input.

\section{Methodology}

Qualitative research: the author builds a preliminary questionnaire and conducts mock interviews in front of 15 experts who are managers of agencies, departments and businesses operating in the field of logistics services, e-commerce, etc. Vietnam aims to learn, discover, adjust, and supplement the observed variables and at the same time check the clarity of words, the ability to express or the content duplication, if any, of the statements in the scale to make the appropriate adjustments. The qualitative research results are the basis for building the official interview questionnaire to test the scale consisting of 07 independent variables, with 29 observed variables, ensuring objectivity and justification for the research results.

Quantitative research: from the survey results of 579 survey questionnaires, the author uses SPSS 22.0 software to analyze data, assess the impact of factors affecting Logistics - E-commerce in Vietnam.

\section{Results}

\subsection{Cronbach's alpha}

All 7 scales have the satisfactory Cronbach's Alpha coefficient since they are greater than 0.6 , the correlation coefficients of the total variables are higher than 0.3; all remaining observations for 7 scales were retained for EFA analysis.

Table 2

Cronbach's alpha results

\begin{tabular}{llll}
\hline Code & Observed variables & Number of observed variables & Cronbach's alpha results \\
\hline CPe & Customer perception & 4 & 0.779 \\
TaS & Technology and security & 5 & 0.888 \\
CPr & Customer protection & 4 & 0.767 \\
EPS & Electronic payment system & 4 & 0.904 \\
HR & Human resources & 4 & 0.897 \\
OaA & Organization and administration & 4 & 0.868 \\
LP & Logistics performance & 4 & 0.770 \\
\hline
\end{tabular}

Source: calculated by the author

\subsection{Linear regression analysis and model testing}

The Durbin-Watson coefficient can be used to test the correlation of adjacent errors. The results show that the Dubin-Watson statistical value of 1,799 is close to 2 , that is, accepting the assumption that there is no first-order series correlation between the residuals.

Table 3

Evaluate the fit of the model

\begin{tabular}{|c|c|c|c|c|c|c|}
\hline \multicolumn{7}{|c|}{ Model Summary } \\
\hline Model & $\mathrm{R}$ & $\mathrm{R}$ square & $\begin{array}{l}\mathrm{R} \text { squared } \\
\text { corrected }\end{array}$ & $\begin{array}{l}\text { Estimated error } \\
\text { standard deviation }\end{array}$ & of & $\begin{array}{l}\text { Durbin-Watson } \\
\text { coefficient }\end{array}$ \\
\hline 1 & $.886^{\mathrm{a}}$ & .686 & .683 & .04797 & & 1.799 \\
\hline
\end{tabular}

Then continue to test the fit of the model to check whether this regression model is suitable with the collected data set and has applied significance through ANOVA test as follows:

Table 5

ANOVA results

\begin{tabular}{cccccc}
\hline & Model & Sum of Squares & Df & Mean Square & F \\
\hline & Regression & 0.682 & 7 & 0.095 & 49.688 \\
& Residual & 0.372 & 168 & 0.002 & \\
\hline & Total & 0.974 & 179 & & \\
\hline
\end{tabular}

a. Dependent Variable: LP

b. Predictors: (Constant). CPe. TaS. CPr. EPS. HR. OaA 
Table 6

Multiple regression results with partial regression coefficients in the model

\begin{tabular}{|c|c|c|c|c|c|c|c|c|}
\hline & \multirow[t]{2}{*}{ Model } & & Unnormalized & \multirow{2}{*}{$\begin{array}{c}\text { Normalized } \\
\text { Beta }\end{array}$} & \multirow[t]{2}{*}{ T-value } & \multirow[t]{2}{*}{ Sig. } & \multicolumn{2}{|c|}{ Multicollinear statistics } \\
\hline & & & B Std. Error & & & & Tolerance & VIF \\
\hline \multirow{7}{*}{1} & (Constant) & 0.978 & 0.026 & & 40.987 & .000 & & \\
\hline & $\mathrm{CPe}$ & 0.252 & 0.029 & 0.195 & 7.511 & .000 & 0.868 & 1.248 \\
\hline & $\mathrm{TaS}$ & 0.288 & 0.018 & 0.327 & 14.884 & .000 & 0.858 & 1.529 \\
\hline & $\mathrm{CPr}$ & 0.129 & 0.017 & 0.122 & 1.001 & .018 & 0.917 & 1.979 \\
\hline & EPS & 0.045 & 0.089 & 0.497 & 6.034 & .000 & 0.816 & 1.286 \\
\hline & HR & 0.066 & 0.01 & 0.279 & 6.574 & .000 & 0.858 & 1.686 \\
\hline & $\mathrm{OaA}$ & 0.052 & 0.01 & 0.686 & 5.079 & .000 & 0.879 & 1.197 \\
\hline
\end{tabular}

From the above results, the equation shows the factors affecting logistics performance in e-commerce:

$$
Y=0.978+0.252 \times C P e+0.288 \times T a S+0.129 \times C P r+0.045 \times E P S+0.066 \times H R+0.052 \times O a A
$$

\section{Conclusion}

At the same time, in order to improve logistics efficiency in e-commerce, it is necessary to pay more attention to the above 7 factors, with details of the important factors being: i) "Demand for online shopping and transactions" ; ii) "Security of online transaction information"; iii) "Dispute settlement and settlement procedures"; iv) "Safety and confidentiality of guest information"; v) "Mode of payment suitable for customers"; vi) "Training human resources for the sector"; vii) "Logistics distribution channel management".

Along with analyzing the situation, the research team proposed some strategic solutions for logistics development, including: 1) Building a logistics model with the connection of e-commerce activities with multimodal logistics in the trend. industrial revolution 4.0; 2) Promote investment in application of science and technology according to the trend of forming the logistics industry, adopt policies to support investment capital for logistics enterprises and encourage high-tech enterprises to participate; 3) Building a logistics center, combined with completing and synchronizing logistics infrastructure; 4) Exploiting a centralized network of industry enterprises, with a variety of online transactions, in order to share and exploit industry resources; 5) Promote training, improve the quality of human resources in the industry, foster human resources at enterprises; 6) Completing the legislation on logistics.

\section{References}

Brosch, T., Pourtois, G., \& Sander, D. (2010). The perception and categorisation of emotional stimuli: A review. Cognition and Emotion, 24(3), 377-400.

Cakir, S. Y., \& EGINLI, A. T. (2013). E-service Quality Factors that Web Sites should have in Creating Electronic Customer Satisfaction: A Research on Online (Clothing) Shopping Sites. International Journal of Business and Management Studies, 5(1), 474-484.

Chakraborty, R., Lee, J., Bagchi-Sen, S., Upadhyaya, S., \& Rao, H. R. (2016). Online shopping intention in the context of data breach in online retail stores: An examination of older and younger adults. Decision Support Systems, 83, 47-56.

Fiske, S. T., Lin, M., \& Neuberg, S. L. (2018). The continuum model: Ten years later. Social cognition, 41-75.

Glover, S., \& Benbasat, I. (2011). A model of e-commerce transaction perceived risk. International Journal of Electronic Commerce, 15(2), 47-78.

Hohenstein, N. O., Feisel, E., \& Hartmann, E. (2014). Human resource management issues in supply chain management research. International Journal of Physical Distribution \& Logistics Management, 44(6), 434-463.

Jing, Y. (2009). On-line Payment and Security of E-commerce. In Proceedings. The 2009 International Symposium on Web Information Systems and Applications (WISA 2009) (p. 46). Academy Publisher.

Menon, S. T. (2012). Human resource practices, supply chain performance, and wellbeing. International Journal of Manpower, 33(7), 769-785.

Metzger, M. J. (2007). Making sense of credibility on the Web: Models for evaluating online information and recommendations for future research. Journal of the American Society for Information Science and Technology, 58(13), 2078-2091.

Okifo, J., \& Igbunu, R. (2015). Electronic Payment System in Nigeria: Its Economic Benefits and Challenges. Journal of Education and practice, 6(16), 56-62.

Panarello, A., Tapas, N., Merlino, G., Longo, F., \& Puliafito, A. (2018). Blockchain and iot integration: A systematic survey. Sensors, 18(8), 2575.

Petronio, S. (2002). Boundaries of privacy: Dialectics of disclosure. Suny Press.

Sharma, K. (2010). An Evaluation of Consumer Privacy Protection in E-Commerce Websites: A Comparative Study of Six E-Stores: Part II. EDPACS, 42(2), 1-19.

Singh, P. R. I. Y. A. N. K. A., Supriya, N., \& Joshna, M. S. (2013). Issues and challenges of electronic payment systems. International Journal for Research in Management and Pharmacy, 2(9), 25-30. 
Smith-Doerflein, K. A., Tracey, M., \& Tan, C. L. (2011). Human resource management and supply chain effectiveness: an exploratory study. International Journal of Integrated Supply Management, 6(3-4), 202-232.

Solvi, A. S., Foss, K., von Soest, T., Roald, H. E., Skolleborg, K. C., \& Holte, A. (2010). Motivational factors and psychological processes in cosmetic breast augmentation surgery. Journal of Plastic, Reconstructive \& Aesthetic Surgery, 63(4), 673-680.

Wong, WPM, Tan, KL, Ida, AK, \& Lim, BCY (2019). The Effect of Technology Trust on Customer E-Loyalty in Online Shopping and The Mediating Effect of Trustworthiness. Journal of Marketing Advances and Practices, 1(2), 38-51.

Yakup, D., \& DIYARBAKIRLIOGLU, I. (2011). A theoritical approach to the role of perception on the consumer buying decision process. Asian Journal of Business and Management Sciences, 1(4), 217-221.

Yuniar, A. D., \& Fibrianto, A. S. (2019, September). The Affect of Technical Familiarity and Consumer Protection Behavior in Using E-Commerce as Platform Online Shopping. In 2019 International Seminar on Application for Technology of Information and Communication (iSemantic) (pp. 300-305). IEEE.

Yu, H. C., Hsi, K. H., \& Kuo, P. J. (2002). Electronic payment systems: an analysis and comparison of types. Technology in Society, 24(3), 331-347. 

distributed under the terms and conditions of the Creative Commons Attribution (CCBY) license (http://creativecommons.org/licenses/by/4.0/). 